\title{
Analisis kemampuan penalaran matematis ditinjau dari persepsi siswa terhadap materi operasi aljabar di kelas VII SMP
}

\author{
Yuni Widiati, Kamid, Evita Anggerein \\ Program Magister Pendidikan Matematika, Pascasarjana, Universitas Jambi, Indonesia \\ E-mail : yuniwidiati31@gmail.com
}

\begin{abstract}
ABSTRAK
Penalaran dalam pembelajaran matematika diperlukan dalam setiap penyelesaian soal matematika. Melalui penalaran, siswa diharapkan dapat melihat bahwa matematika merupakan kajian yang masuk akal atau logis. Persepsi yang baik terhadap pembelajaran matematika membuat siswa senang dan antusias mengikuti pembelajaran sehingga akan menunjang kemampuan penalaran matematisnya. Penelitian ini bertujuan untuk mengetahui kemampuan penalaran matematis ditinjau dari persepsi siswa terhadap materi aljabar di kelas VII SMP. Jenis penelitian yang digunakan adalah penelitian kualitatif deskriptif. Prosedur penelitian ini terdiri tahap persiapan, peneliti melakukan permintaan izin untuk melakukan penelitian, menyusun instrumen penelitian, dan validasi instrumen penelitian yang berupa angket, soal tes dan pedoman wawancara. Lalu tahap pelaksanaan, peneliti memberikan angket persepsi siswa terhadap materi operasi aljabar, menganalisis hasil angket persepsi lalu membagi siswa menjadi kelompok, menentukan subjek penelitian, memberikan soal penalaran matematis kepada subjek penelitian, mengoreksi jawaban siswa, melakukan wawancara. Selanjutnya data yang diperoleh dalam penelitian ini dianalisis sesuai dengan teknik analisis data. Subjek penelitian adalah siswa yang dikelompokkan berdasarkan persepsi positif dan persepsi negative. Dari hasil penelitian dapat diketahui bahwa persepsi siswa terhadap materi operasi aljabar ialah sebanyak 5 siswa $(23,81 \%)$ menyatakan sangat positif, 4 siswa $(19,04 \%)$ menyatakan positif, 10 siswa $(47,62 \%)$ menyatakan negatif, dan 2 siswa $(9,53 \%)$ menyatakan sangat negatif. Maka persepsi siswa terhadap materi operasi aljabar dinyatakan negatif lebih dominan, karena frekuensi terbanyak berada pada kategori negatif, yaitu sebanyak 10 siswa. Kemampuan penalaran matematis siswa pada kelompok persepsi sangat positif dan positif termasuk kedalam kemampuan penalaran matematis deduktif sedangkan kelompok penalaran matematis negatif dan sangat negatif termasuk dalam kemampuan penalaran matematis pra deduktif.
\end{abstract}

Kata Kunci: Penalaran Matematis; Persepsi; Aljabar.

\begin{abstract}
This study aims to determine mathematical reasoning abilities in terms of students' perceptions of algebraic material in class VII SMP. The type of research used is descriptive qualitative research. The procedure of this research consisted of the preparatory stage, the researcher made a request for permission to conduct research, compiled research instruments, and validated the research instruments in the form of questionnaires, test questions and interview guidelines. Then the implementation phase, the researcher gave questionnaire students 'perceptions of algebraic operating material, analyzed the results of the perception questionnaire then divided students into groups, determined the research subjects, gave mathematical reasoning questions to the research subjects, corrected students' answers, conducted interviews. Furthermore the data obtained in this study were analyzed according to data analysis techniques. The subjects of this study were students who were grouped based on positive perceptions and negative perceptions. From the results of this study it can be seen that students' perceptions of algebraic operating material in class VII were 5 students (23.81\%) stated very positive, 4 students $(19.04 \%)$ stated positive, 10 students $(47,62 \%)$ stated negative, and 2 students $(9.53 \%)$ stated very negative. Then the students' perception of algebraic operations material is stated to be negative more dominant, because the highest frequency is in the negative category, which is 10 students. Mathematical reasoning ability of students in the very positive and positive perception group includes the deductive mathematical reasoning ability while the negative and very negative mathematical reasoning group belongs to the pre-deductive mathematical reasoning ability.
\end{abstract}

Keywords: Mathematical Reasoning; Perception; Algebra. 


\section{PENDAHULUAN}

Matematika sebagai salah satu mata pelajaran pada setiap jenjang pendidikan formal dipandang memegang peranan yang sangat penting dalam penguasaan ilmu pengetahuan dan teknologi. Sejalan dengan kurikulum 2013 pemerintah juga menyatakan pentingnya kemampuan penalaran seperti yang dijabarkan dalam permendikbud Nomor 64 tahun 2013 mengenai standar isi yang diatur bagi kelas VII, VIII, dan IX SMP atau sederajat, disebutkan dalam salah satu keterampilan yang harus dikuasai yaitu menalar dalam ranah konkret dan ranah abstrak terkait dengan pengembanganyang dipelajarinya di sekolah secara mandiri dan mampu menggunakan metode sesuai kaidah keilmuan. Dalam NCTM ada lima standar proses pembelajaran matematika yaitu belajar untuk memecahkan masalah, belajar untuk bernalar dan pembuktian, belajar untuk berkomunikasi, belajar untuk mengaitkan ide dan belajar untuk mempresentasikan. Hal demikian menunjukkan bahwa kemampuan penalaran merupakan kemampuan yang penting dalam pembelajaran matematika.

Penalaran dalam pembelajaran matematika diperlukan dalam setiap penyelesaian soal matematika. Melalui penalaran, siswa diharapkan dapat melihat bahwa matematika merupakan kajian yang masuk akal atau logis. Dengan demikian siswa merasa yakin bahwa matematika dapat dipahami, dipikirkan, dibuktikan, dan dapat dievaluasi untuk mengerjakan hal-hal yang berhubungan dengan bernalar. Istilah penalaran matematika atau biasa yang dikenal dengan penalaran matematis dalam beberapa literatur disebut dengan mathematical reasoning. Brodie (2010, p.7) menyatakan bahwa penalaran matematis adalah penalaran dengan objek matematika. Objek matematika dalam hal ini adalah cabang-cabang matematika yang dipelajari seperti statistika, aljabar, geometri dan sebagainya. Penalaran merupakan tahapan berpikir matematika tingkat tinggi, mencakup kapasitas untuk berpikir secara logis dan sistematis.

Shadiq (2004, p.2) menjelaskan penalaran (jalan pikiran atau reasoning) sebagai proses berpikir yang berusaha menghubung-hubungkan fakta-fakta atau evidensi-evidensi yang diketahui menuju kepada suatu kesimpulan. Selain itu Nurahman (2020, p.12) menjelaskan penalaran matematika adalah salah satu proses berpikir yang dilakukan dengan cara menarik suatu kesimpulan.

Persepsi siswa terhadap pembelajaran materi aljabar juga sangat mempengaruhi hasil penalaran matematis siswa. Menurut Slameto (2010, p.102) menyatakan persepsi adalah proses yang berkaitan dengan masuknya pesan atau informasi kedalam otak manusia, melalui persepsi manusia terus menerus mengadakan hubungan dengan lingkungannya. Hubungan ini dilakukan lewat inderanya, yaitu indera pengelihat, pendengar, peraba, perasa, dan pencium. Sedangkan Menurut Solso, Maclin, \& Maclin (2007, p.75) persepsi melibatkan kognisi tingkat tinggi dalam penginterpretasian terhadap informasi sensorik. Persepsi dibagi menjadi dua bentuk yaitu positif dan negatif persepsi positif merupakan penilaian individu terhadap suatu objek atau informasi dengan pandangan yang positif atau sesuai dengan yang diharapkan dari objek yang dipersepsikan atau dari aturan yang ada.

Penyebab munculnya persepsi positif seseorang karena adanya kepuasan individu terhadap objek yang menjadi sumber persepsinya, adanya pengetahuan individu, serta adanya pengalaman individu terhadap objek yang dipersepsikan. Sedangkan, persepsi negatif merupakan persepsi individu terhadap objek atau informasi tertentu dengan pandangan yang negatif, berlawanan dengan yang diharapkan dari objek yang dipersepsikan atau dari aturan yang ada. Penyebab munculnya persepsi negatif seseorang dapat muncul karena adanya ketidakpuasan individu terhadap objek yang menjadi sumber persepsinya, adanya ketidaktahuan individu serta tidak adanya pengalaman inidvidu terhadap objek yang 
dipersepsikan dan sebaliknya.

MenurutPurwanto(2009),Jikaprosespembelajaranmenyenangkanmakaakanmemunculkan persepsi yang baik bagi siswa terhadap pembelajaran matematikanya. Persepsi merupakan suatu proses menginterpretasi atau menafsirkan informasi yang diperoleh melalui alat indera manusia. Persepsi yang baik terhadap pembelajaran matematika membuat siswa senang dan antusias mengikuti pembelajaran sehingga akan menunjang kemampuan penalaran matematisnya. Jadi, persepsi siswa tentang pembelajaran matematika merupakan salah satu faktor yang berpengaruh terhadap kemampuan penalaran matematis siswa.

Berdasarkan observasi, siswa yang memiliki persepsi positif terhadap pelajaran materi aljabar akan merasa senang dalam mengikuti pelajaran sehingga siswa akan memperhatikan pembelajaran yang berlangsung dan ikut serta aktif dalam kegiatan pembelajaran. Jika siswa memiliki persepsi negatif terhadap cara mengajar pembelajaran matematika, maka siswa kurang memperhatikan materi yang diajarkan dan siswa tidak aktif dalam pembelajaran, hal tersebut berdampak pada kemampuan penalaran matematisnya. Namun banyak dijumpai dilapangan bahwa kemampuan penalaran matematis yang diperoleh siswa tidak selalu sejalan dengan proses selama pembelajaran berlangsung. Misalnya saja ada beberapa siswa yang tampak kurang tertarik dengan pembelajaran materi aljabar yang dilakukan, namun saat tes diberikan kemampuan penalaran matematis ternyata justru lebih baik ketimbang temannya yang tampak benar-benar antusias dan serius dalam pembelajaran dengan materi ajar yang sama. Hal ini lah yang mendasari peneliti melakukan penelitian ini yaitu untuk mengetahui kemampuan penalaran siswa ditinjau dari persepsi siswa terhadap materi operasi aljabar.

\section{METODE PENELITIAN}

Penelitian yang digunakan dalam penelitian ini termasuk ke dalam penelitian kualitatif dengan pendekatan deskriptif. Penelitian kualitatif menurut Creswell (2016:4-5) merupakan metode-metode untuk mengeksplorasi dan memahami makna yang oleh sejumlah individu atau sekelompok orang dianggap berasal dari masalah sosial atau kemanusiaan. Kualitatif deskriptif merupakan suatu penelitian yang memaparkan hasil penelitian mengenai situasi yang diteliti lalu disajikan dalam bentuk uraian naratif. Proses penelitian kualitatif ini melibatkan upaya-upaya penting, seperti mengajukan pertanyaa-pertanyaan dan prosedurprosedur, mengumpulkan data yang spesifik dari para partisipan, menganalisis data secara induktif mulai dari tema-tema yang khusus ke tema-tema yang umum, dan menafsirkan makna data. Laporan akhir untuk penelitian ini memiliki struktur atau kerangka yang fleksibel.

Subjek dalam penelitian ini adalah siswa kelas VII SMP N 1 Kota Jambi. Teknik pemilihan subjek yang digunakan adalah teknik snowball sampling karena sampel tidak bisa dipilih secara acak. Dalam penelitian ini, sampel atau subjek penelitian yang dipilih adalah subjek penelitian yang dapat memberikan informasi sebanyak mungkin dalam penelitian ini. Penentuan subjek penelitian didasarkan pada persepsi siswa terhadap materi aljabar.

Teknik pengumpulan data dalam penelitian ini adalah kuesioner yang dilakukan dengan menyebarkan angket penelitian kepada siswa kelas VII SMP Negeri 1 Kota Jambi yang berjumlah 21 orang. Setelah data penelitian terkumpul dilakukan analisis menggunakan analisis deskriptif kuantitatif, kemudian siswa dikelompokkan menjadi 4 kelompok persepsi yaitu sangat positif, positif, negatif dan sangat negatif. Siswa dari setiap kelompok persepsi dipilih masing-masing 1 yang memiliki skor angket tertinggi di masing-masing 
kelompok untuk menjadi subjek penelitian. Lalu subjek penelitian tersebut diberikan soal kemampuan penalaran matematis yang berjumlah 2 soal. Setelah data penelitian tersebut terkumpul dilakukan analisis deskriptif berdasarkan hasil jawaban siswa dan kemudian dilakukan wawancara sebagai triangulasi.

Menurut Creswell (2016, p.260) analisis data dalam penelitian kualitatif akan berlangsung bersamaan dengan bagian-bagian lain dari pengembangan penelitian kualitatif, yaitu pengumpulan data dan penulisan temuan. Langkah-langkah analisis data dalam penelitian kualitatif ialah mengolah dan mempersiapkan data untuk dianalisis. Langkah ini melibatkan transkrip wawancara, men-scanning materi, mengetik data lapangan, atau memilah miah dan meyusun data tersebut ke dalam jenis-jenis yang berbeda tergantung pada sumber informasi (Creswell, 2016, p.264). Dalam penelitian ini peneliti akan mengolah dan mempersiapkan data berupa respon siswa terhadap angket persepsi siswa, hasil jawaban siswa dalam tes kemampuan penalaran matematis materi operasi aljabar serta hasil wawancara. Data akan diolah dengan mengkonversi hasil angket persepsi siswa, mengoreksi jawaban tes kemampuan penalaran matematis siswa serta mentranskip hasil wawancara.

Hasil dari respon siswa pada angket persepsi siswa akan dikonversikan menjadi kategori persepsi sangat positif, positif, negatif, dan sangat negatif, hasil dari tes kemampuan penalaran matematis siswa dan hasil wawancara akan diurutkan dan disesuaikan dengan indikator kemampuan penalaran matematis. Peneliti juga akan melakukan kredibilitas data pada tahap ini dengan menggunakan triangulasi.

Triangulasi adalah teknik pemeriksaan keabsahan data yang memanfaatkan sesuatu yang lain di luar data untuk keperluan pengecekan atau sebagai pembanding terhadap data itu. Dalam hal ini Triangulasi dapat dikatakan sebagai teknik pengumpulan data yang sekaligus menguji kredibiitas atau keabsahan data. Triangulasi diartikan sebagai teknik pengumpulan data yang bersifat menggabungkan dari berbagai teknik pengumpulan data dari sumber yang telah ada (Sugiyono, 2014, p.83), bila peneliti melakukan pengumpulan data dengan triangulasi, maka sebenarnya peneliti mengumpulkan data yang sekaligus melakukan uji kredibilitas atau keabsahan data, yaitu mengecek kredibilitas data dengan berbagai teknik pengumpulan data dan berbagai sumber.

\section{HASIL DAN PEMBAHASAN}

Persepsi Siswa Terhadap Materi Operasi Aljabar. Berdasarkan hasil penelitian diatas, angket persepsi yang terdiri dari 15 pernyataan yang diajukan kepada siswa kelas VII yang berjumlah 21 siswa, dapat diketahui rerata persepsi siswa terhadap materi aljabar sebesar 49,62. nilai sering muncul sebesar 42 dan simpangan baku sebesar 8,53. Sedangkan skor tertinggi sebesar 65 dan skor terendah sebesar 35. Dari rerata ideal dan simpangan baku ideal tersebut, dapat dilakukan klasifikasi mengenai persepsi siswa terhadap materi operasi aljabar yaitu kategori sangat positif, positif, negatif, dan sangat negatif.

Dari hasil perhitungan diatas daapat diketahui bahwa persepsi siswa terhadap materi operasi aljabar di kelas VII SMP ialah sebanyak 5 siswa $(23,81 \%)$ menyatakan sangat positif, 4 siswa $(19,04 \%)$ menyatakan positif, 10 siswa $(47,62 \%)$ menyatakan negatif, dan 2 siswa $(9,53 \%)$ menyatakan sangat negatif. Maka persepsi siswa terhadap materi operasi aljabar dinyatakan negatif lebih dominan, karena frekuensi terbanyak berada pada kategori negatif, yaitu sebanyak 10 siswa.

Dari hasil analisis butiran pernyataan pada angket persepsi yang dijawab oleh siswa, pada 
poin 1 "materi aljabar yang diberikan guru, saya terina dengan jelas" rata-rata siswa memilih setuju. Pada poin 2 " materi aljabar yang diberikan guru, saya terima dengan sangat cepat" rata-rata siswa memilih ragu-ragu. Pada poin 3 "materi aljabar yang diterangkan guru, saya terima sebagian kecil saja" rata rata siswa memilih ragu-ragu. Pada poin 4, materi aljabar yang diterangkan guru saya terima dengan jelas tetapi mudah hilang" rata-rata siswa memilih ragu ragu. Pada poin 5 "Materi aljabar yang diberikan guru saya terima dengan mendengar dan memahami" rata rata siswa memilih setuju. Pada poin 6 "Materi aljabar saya mengerti sebagian saja" rata-rata siswa memilih tidak setuju. Pada poin 7 "materi aljabar saya pahami secara keseluruhan" rata-rata siswa memilih ragu-ragu. Pada poin 8 "materi aljabar tidak ada hubungannya dengan materi pelajaran lain" rata-rata siswa memilih ragu-ragu. Pada poin 9 "Materi aljabar saling berkaitan dengan materi matematika yang lain" rata-rata siswa memilih ragu-ragu. Pada poin 10 "Materi aljabar tidak saya pahami dalam kehidupan sehari-hari" rata-rata siswa memilih ragu-ragu. Pada poin 11 "Materi aljabar sangat mudah" rata-rata siswa memilih ragu-ragu. Pada poin 12 "materi aljabar sangat menyenangkan" rata-rata siswa memilih ragu-ragu. Pada poin 13 "materi aljabar sangat bermanfaat" ratarata siswa memilih ragu-ragu. Pada poin 14 "Materi aljabar menyebabkan sakit kepala dan sakit perut" rata-rata siswa memilih ragu-ragu. Dan terakhir poin 15 "Materi aljabar menyebabkan stress (kesedihan)" rata-rata siswa memilih ragu-ragu. Dari penjelasan diatas dapat diketahui bahwa banyak siswa yang masih ragu-ragu dengan materi aljabar yang telah mereka pelajari.

Proses Penalaran Matematis Siswa berdasarkan Persepsi Siswa terhadap Materi Operasi Aljabar Pada Kategori Sangat Positif. Berdasarkan paparan data di atas, maka diperoleh beberapa temuan peneliti terkait proses penalaran matematis siswa subjek kelompok persepsi sangat positif. Berdasarkan paparan data diatas maka diketahui bahwa subjek kelompok persepsi sangat positif mampu memenuhi indikator memahami masalah (Understanding the Problem) yaitu subjek mampu menjelaskan bagaimana bisa menetapkan hal-hal sebagai yang diketahui dan ditanyakan dan juga semua subjek mampu memenuhi indikator merencanakan pemecahan masalah (Devising a Plan) yaitu dapat menjelaskan rencana yang dibuat. subjek mampu melaksanakan pemecahan masalah (Carrying Out the Plan) yaitu mampu mengoperasikan dengan benar dan dapat menyusun bukti pemecahan yang dilakukan. Serta pada subjek kelompok tinggi semua juga mampu menafsirkan hasil (Looking Back) yaitu dapat menarik kesimpulan dari pernyataan dan dapat memeriksa kesahihan suatu argument yang terbukti dari kesimpulan akhir.

Dilihat dari segi penalarannya kelompok persepsi sangat positif dalam mengerjakan soal nomor 1 dan 2 menggunakan penalaran deduktif karena dapat diketahui bahwa mereka mengerjakan soal dengan langkah pertama yaitu dengan mengambarkan yang diketahui pada soal. Setelah itu mengoperasikannya bilangan dengan rumus yang menurut mereka benar. Seperti yang dikatakan oleh Bakry dalam Wardhani \& Wihardit $(2008$, p.11) penalaran yang berkaitan dengan rasionalisme, bersumber pada rasio. Dari analisis penalaran matematis maka subjek kelompok persepsi sangat positif mempunyai penalaran deduktif sangat baik dalam menyelesaikan soal operasi aljabar

\section{Proses Penalaran Matematis Siswa pada Siswa berdasarkan Persepsi Siswa terhadap} Materi Operasi Aljabar Pada Kategori Persepsi Positif. Berdasarkan paparan data di atas, maka diperoleh beberapa temuan peneliti terkait proses penalaran matematis siswa subjek kelompok persepsi positif dalam memecahkan masalah. Berdasarkan paparan data diatas maka diketahui bahwa subjek kelompok persepsi positif mampu memenuhi indikator memahami masalah (Understanding the Problem) yaitu subjek mampu menjelaskan bagaimana bisa menetapkan hal-hal sebagai yang diketahui dan ditanyakan dan juga semua subjek mampu memenuhi indikator merencanakan pemecahan masalah (Devising a Plan) 
yaitu dapat menjelaskan rencana yang dibuat. subjek mampu melaksanakan pemecahan masalah (Carrying Out the Plan) yaitu mampu mengoperasikan dengan benar dan dapat menyusun bukti pemecahan yang dilakukan. Tetapi pada subjek kelompok persepsi positif semua kurang mampu menafsirkan hasil (Looking Back) yaitu belum dapat menarik kesimpulan dari pernyataan dan dapat memeriksa kesahihan suatu argument yang terbukti dari kesimpulan akhir.

Dilihat dari segi penalarannya kelompok persepsi positif dalam mengerjakan soal nomor 1 dan 2 menggunakan penalaran deduktif karena dapat diketahui bahwa mereka mengerjakan soal dengan langkah pertama yaitu dengan menggambarkan apa yang diketahui pada soal. Setelah itu mengoperasikannya bilangan dengan rumus yang menurut mereka benar, tetapi dalam kategori persepsi positif mereka belum bisa membuat kesimpulan dengan baik dan benar. Seperti yang dikatakan oleh Bakry dalam Wardhani \& Wihardit (2008, p.11) penalaran yang berkaitan dengan rasionalisme, bersumber pada rasio. Romadhina, $\mathrm{D}$ (2007, p.12) juga menambahkan bawah Deduksi adalah proses penalaran yang bergerak dari halhal yang umum menuju hal-hal yang khusus. Dari analisis penalaran matematis maka subjek kelompok persepsi positif mempunyai penalaran deduktif yang baik dalam menyelesaikan soal operasi aljabar

Proses Penalaran Matematis Siswa pada Siswa berdasarkan Persepsi Siswa terhadap Materi Operasi Aljabar Pada Kategoru Persepsi Negatif. Berdasarkan paparan data di atas, maka diperoleh beberapa temuan peneliti terkait proses penalaran matematis siswa subjek kelompok persepsi negatif dalam memecahkan masalah. Berdasarkan paparan data diatas maka diketahui bahwa subjek kelompok persepsi negatif mampu memenuhi indikator memahami masalah (Understanding the Problem) yaitu subjek mampu menjelaskan bagaimana bisa menetapkan hal-hal sebagai yang diketahui dan ditanyakan tetapi semua subjek kurang mampu merencanakan pemecahan masalah (Devising a Plan) yaitu belum bisa menjelaskan rencana yang dibuat. Subjek kurang mampu dalam melaksanakan pemecahan masalah (Carrying Out the Plan) yaitu belum mampu mengoperasikan dengan benar dan dapat menyusun bukti pemecahan yang dilakukan. Serta pada semua subjek kelompok persepsi negatif juga belum mampu menafsirkan hasil (Looking Back) yaitu belum mampu menarik kesimpulan dari pernyataan dan dapat memeriksa kesahihan suatu argument yang terbukti dari kesimpulan akhir.

Dilihat dari segi penalarannya kelompok persepsi negatif dalam mengerjakan soal nomor 1 dan 2 menggunakan penalaran pra deduktif karena dapat diketahui bahwa mereka mengerjakan soal dengan langkah pertama yaitu dengan menggambarkan apa yang diketahui pada soal. Tetapi mereka belum bisa mengoperasikannya bilangan dengan rumus yang menurut mereka benar. Dan juga tidak bisa membuat kesimpulan dengan tepat. Dari analisis penalaran matematis maka seluruh subjek kelompok persepsi negatif mempunyai penalaran pra deduktif dalam menyelesaikan masalah dan seluruh subjek sudah memenuhi indikator pemecahan masalah dalam memahami masalah tetapi subjek kategori persepsi negatif kurang mampu dalam merencanakan penyelesaian, melaksanakan rencana penyelesaian dan menafsirkan hasil.

Proses Penalaran Matematis Siswa pada Siswa berdasarkan Persepsi Siswa terhadap Materi Operasi Aljabar Persepsi Sangat Negatif. Berdasarkan paparan data di atas, maka diperoleh beberapa temuan peneliti terkait proses penalaran matematis siswa subjek kelompok persepsi sangat negatif dalam memecahkan masalah. Berdasarkan paparan data diatas maka diketahui bahwa semua subjek kelompok persepsi sangat negatif mampu memenuhi indikator memahami masalah (Understanding the Problem) yaitu subjek mampu menjelaskan bagaimana bisa menetapkan hal-hal sebagai yang diketahui dan ditanyakan 
tetapi semua subjek kurang mampu merencanakan pemecahan masalah (Devising a Plan) yaitu belum bisa menjelaskan rencana yang dibuat. Semua subjek kurang mampu dalam melaksanakan pemecahan masalah (Carrying Out the Plan) yaitu belum mampu mengoperasikan dengan benar dan dapat menyusun bukti pemecahan yang dilakukan. Serta pada semua subjek kelompok persepsi sangat negatif juga belum mampu menafsirkan hasil (Looking Back) yaitu belum mampu menarik kesimpulan dari pernyataan dan dapat memeriksa kesahihan suatu argument yang terbukti dari kesimpulan akhir.

Dilihat dari segi penalarannya kelompok persepsi sangat negatif dalam mengerjakan soal nomor 1 dan 2 menggunakan penalaran pra deduktif karena dapat diketahui bahwa mereka mengerjakan soal dengan langkah pertama yaitu dengan menggambarkan apa yang diketahui pada soal. Tetapi mereka belum bisa mengoperasikannya bilangan dengan rumus yang menurut mereka benar. Dan juga tidak bisa membuat kesimpulan dengan tepat. Dari analisis penalaran matematis maka seluruh subjek kelompok persepsi sangat negative mempunyai penalaran pra deduktif dalam menyelesaikan masalah dan seluruh subjek sudah memenuhi indikator pemecahan masalah dalam memahami masalah tetapi subjek kelompok persepsi sangat negatif kurang mampu dalam merencanakan penyelesaian, melaksanakan rencana penyelesaian dan menafsirkan hasil.

\section{SIMPULAN}

Berdasarkan hasil penelitian dan pembahasan, dapat disimpulkan bahwa proses penalaran matematis siswa berdasarkan persepsi siswa terhadap materi operasi aljabar dilihat dari segi penalarannya pada kelompok persepsi sangat positif dalam mengerjakan soal nomor 1 dan 2 menggunakan penalaran deduktif karena dapat diketahui bahwa mereka mengerjakan soal dengan langkah pertama yaitu dengan mengambarkan yang diketahui pada soal. Setelah itu mengoperasikannya bilangan dengan rumus yang menurut mereka benar. Dari analisis penalaran matematis maka subjek kelompok persepsi sangat positif mempunyai penalaran deduktif sangat baik dalam menyelesaikan soal operasi aljabar

Dilihat dari segi penalarannya kelompok persepsi positif dalam mengerjakan soal nomor 1 dan 2 menggunakan penalaran deduktif karena dapat diketahui bahwa mereka mengerjakan soal dengan langkah pertama yaitu dengan menggambarkan apa yang diketahui pada soal. Setelah itu mengoperasikannya bilangan dengan rumus yang menurut mereka benar, tetapi dalam kategori persepsi positif mereka belum bisa membuat kesimpulan dengan baik dan benar. Dari analisis penalaran matematis maka subjek kelompok persepsi positif mempunyai penalaran deduktif yang baik dalam menyelesaikan soal operasi aljabar

Dilihat dari segi penalarannya kelompok persepsi negatif dalam mengerjakan soal nomor 1 dan 2 menggunakan penalaran pra deduktif karena dapat diketahui bahwa mereka mengerjakan soal dengan langkah pertama yaitu dengan menggambarkan apa yang diketahui pada soal. Tetapi mereka belum bisa mengoperasikannya bilangan dengan rumus yang menurut mereka benar. Dan juga tidak bisa membuat kesimpulan dengan tepat. Dari analisis penalaran matematis maka seluruh subjek kelompok persepsi negatif mempunyai penalaran pra deduktif dalam menyelesaikan masalah dan seluruh subjek sudah memenuhi indikator pemecahan masalah dalam memahami masalah tetapi subjek kategori persepsi negatif kurang mampu dalam merencanakan penyelesaian, melaksanakan rencana penyelesaian dan menafsirkan hasil.

Dilihat dari segi penalarannya kelompok persepsi sangat negatif dalam mengerjakan soal nomor 1 dan 2 menggunakan penalaran pra deduktif karena dapat diketahui bahwa 
mereka mengerjakan soal dengan langkah pertama yaitu dengan menggambarkan apa yang diketahui pada soal. Tetapi mereka belum bisa mengoperasikannya bilangan dengan rumus yang menurut mereka benar. Dan juga tidak bisa membuat kesimpulan dengan tepat. Dari analisis penalaran matematis maka seluruh subjek kelompok persepsi sangat negative mempunyai penalaran pra deduktif dalam menyelesaikan masalah dan seluruh subjek sudah memenuhi indikator pemecahan masalah dalam memahami masalah tetapi subjek kelompok persepsi sangat negatif kurang mampu dalam merencanakan penyelesaian, melaksanakan rencana penyelesaian dan menafsirkan hasil.

\section{DAFTAR RUJUKAN}

Brodie K. (2010) Mathematical Reasoning Through Tasks: Learners' Responses. In: Brodie K. (eds) Teaching Mathematical Reasoning in Secondary School Classrooms (pp. 43-56). Springer, Boston, MA. DOI: 10.1007/978-0-387-09742-8 3

Creswell, J.W. (2016.) RESEARCH DESIGN, Qualitative, Quantitative, and Mixed Methods Approaches, Fourth Edition. Thousand Oaks, CA: Sage

Nurahman, I. (2020). Pembelajaran Kooperatif Tipe Team-Accelerated Instruction (TAI) Untuk Meningkatkan Kemampuan Penalaran dan Komunikasi Matematika Siswa SMP. Pasundan Journal of Mathematics Education (PJME), 1(1), 96-130. DOI: 10.5035/ pjme.v1i1.2369

Purwanto. (2009). Evaluasi Hasil Belajar. Surakarta, Indonesia: Pustaka Pelajar.

Romadhina, D. (2007). Pengaruh Kemampuan Penalaran dan Kemampuan Komunikasi Matematik terhadap Kemampuan Menyelesaikan Soal Cerita Pada Pokok Bahasan Bangun Ruang Sisi Lengkung Siswa Kelas IX SMP Negeri 29 Semarang Melalui Model Pembelajaran Pemecahan Masalah. Disertasi. Universitas Negeri Semarang, Indonesia. Retrieved from http://lib.unnes.ac.id/id/eprint/1075

Shadiq, F. (2009).Model-Model Pembelajaran Matematika SMP. Jakarta, Indonesia: Nurul Hidayah. Depdiknas.

Slameto. (2010). Belajar dan Faktor-Faktor yang mempengaruhinya. Jakarta, Indonesia: Rineka Cipta.

Solso, R. L., Maclin, O. H., \& Maclin, M. K. (2008). Psikologi Kognitif(8th ed). Jakarta, Indonesia: Erlangga.

Sugiyono. (2014). Metode Penelitian Kuantitatif Kualitatif dan R\&D. Bandung, Indonesia: Alfabeta.

Wardhani, I. G. A. K., \& Wihardit, K. (2008). Penelitian Tindakan Kelas. Jakarta, Indonesia: Universitas Terbuka. 